\title{
Supplementing pasture-fed dairy cows with pasture silage, maize silage, Lotus silage or sulla silage in summer - does it increase production?
}

\author{
S.L. WOODWARD ${ }^{1}$, A.V. CHAVES ${ }^{2}$, G.C. WAGHORN ${ }^{2}$ and P.G. LABOYRIE ${ }^{1}$ \\ ${ }^{1}$ Dexcel, Private Bag 3221, Hamilton \\ ${ }^{2}$ AgResearch Grasslands, Private Bag 11008, Palmerston North \\ sharon.woodward@dexcel.co.nz
}

\begin{abstract}
Forages suitable for supplementing pasture-fed dairy cows over summer-autumn must provide adequate dry matter (DM) and increase milk yield above that produced by cows grazing normal ryegrass/white clover pasture, without compromising milk composition. A trial was conducted in January-February 2001 to compare the benefits obtained from feeding four types of silage. There were two silages that contained condensed tannins (CT) (birdsfoot trefoil (Lotus corniculatus) and sulla (Hedysarum coronarium)), maize silage or traditional ryegrass-dominant pasture silage, all fed at 5 $\mathrm{kg} \mathrm{DM} / \mathrm{cow} / \mathrm{d}$ with restricted pasture. Cows on the restricted pasture (control) treatment and those fed the silage treatments were offered an allowance of $25 \mathrm{~kg}$ DM pasture/cow/d, while the full pasture cows were offered $50 \mathrm{~kg}$ DM pasture/cow/d. Silage supplementation, regardless of silage type, increased both total dry matter intake (DMI) and milk production compared with the restricted pasture treatment. Cows on the Lotus silage supplement, and the full pasture treatment had significantly higher milk yields than the other silage-supplemented cows, all of which had similar milk yields. For the Lotus silage treatment, the high milk yield was probably due to a combination of the higher nutritive value of the silage, and to the action of CT, because the total DMI of the cows on the Lotus silage was the same as that of cows on the pasture silage and maize silage. The high milk yield of the full pasture treatment was mainly a result of the cows having a significantly higher total DMI than cows on all the other treatments. This trial has demonstrated the potential benefit of silage supplementation, particularly with Lotus silage, for increased milksolids yield in summerautumn when low pasture growth rates and quality may otherwise limit production.
\end{abstract}

Keywords: condensed tannins, dairy cows, Lotus, maize, milksolids, ryegrass, silage, sulla, supplementation

\section{Introduction}

Pasture-based dairy farming in New Zealand is characterised by low production costs and high pasture utilisation. However, this reliance on pasture often means that production per cow is low by world standards (Bryant \& Morgan 1992) and milk production on New Zealand dairy farms drops sharply during the summer-autumn months due largely to decreases in the availability and quality of ryegrass pastures in this period (Clark 1995). In the North Island, for example, the decline in milksolids production can be as high as $19 \%$ per month compared with a theoretical decline of $7 \%$ per month based on a normal calving spread and dairy cow physiology. Developments in dairy farm management, such as strategic nitrogen fertiliser use, supplementary feed use and irrigation to increase pasture growth have considerably increased milk production and lactation lengths, and flattened the lactation curve slightly. But despite these developments, daily milk yields still depend on the dry matter intake of pasture that can be achieved (Mackle \& Bryant 1994). Maintenance of high pasture quality will assist in achieving this, but even then it is likely that the inherent characteristics of pasture as a feed, such as high fibre content, will limit dry matter intake (DMI) to levels that constrain milk yields to $25-30$ litres/day. While feeding grain- and concentrate-based diets similar to the total mixed ration (TMR) systems used in America can overcome many of these problems these systems are unlikely to be economically viable in New Zealand at present costs. A more viable option may be to retain a pasture-based system and supplement cows with forages that will meet the nutrient demands of the lactating dairy cow.

Alternative forages that can increase milk production by dairy cows without compromising milk composition must provide for high DMI, optimal rumen fermentation, and improved digestion kinetics (Waghorn 2002). Two legumes that contain condensed tannins (CT) and have the nutritional potential to fulfil some of these requirements are birdsfoot trefoil (Lotus corniculatus) and sulla (Hedysarum coronarium). CT are phenolic compounds that bind to plant protein complexes in the rumen ( $\mathrm{pH}$ range $3.5-7.0$ ) and therefore reduce microbial degradation of protein to ammonia in the rumen. The CT-protein complexes dissociate below $\mathrm{pH} 3.5$, increasing non-ammonia nitrogen flux to the abomasum and small intestine (Terrill et al. 1992), and increasing the apparent absorption of amino acids from the small intestine 
(Waghorn et al. 1987). In effect the CT convert degradable plant proteins into protected or rumen bypass proteins, thus increasing the amount of protein available to the cow for milk production.

This paper reports on a short-term trial that compared the production responses obtained from supplementing cows on a restricted pasture allowance with either CTcontaining silages (Lotus silage or sulla silage), maize silage or ryegrass-dominant pasture silage.

\section{Methods}

\section{Trial design}

The trial was conducted over 4 weeks in JanuaryFebruary 2001 at Dexcel's No 5 Dairy, Hamilton using 60 multiparous Friesian dairy cows. Cows were allocated to one of six treatment herds which were balanced for initial daily milksolids yield (milkfat plus milk protein yield; MS) and liveweight. These data for the uniformity period were collected over two days in the week preceding the trial when all cows were grazing the same ryegrass/white clover pasture. Cows on the restricted pasture (control) treatment and those fed the silage treatments grazed similar ryegrass-dominant pasture offered at a pre-grazing allowance of $25 \mathrm{~kg} \mathrm{DM} /$ cow/d, while the full pasture cows were offered $50 \mathrm{~kg}$ $\mathrm{DM} / \mathrm{cow} / \mathrm{d}$. Either pasture silage, maize silage, Lotus silage or sulla silage ( $5 \mathrm{~kg} \mathrm{DM} / \mathrm{cow} / \mathrm{d}$ ) was fed daily in the paddocks to four herds of cows on the restricted pasture allowance $(25 \mathrm{~kg} \mathrm{DM} / \mathrm{cow} / \mathrm{d})$ using portable feed troughs (two troughs per 10 cow herd). Measurements (see below) were made over 3 consecutive days at the end of each week when cows were split into two separate replicate groups per treatment. The cows were split into the same replicate groups each week to ensure consistency for statistical analysis of data and to minimise any adverse behavioural activity between the cows.

\section{Grazing management and pasture measurements}

Pre-grazing herbage mass was determined using either calibrated visual assessment on the four nonmeasurement days each week, or using calibrated rising plate measurements on the three measurement days each week (calibration cuts and measurement of forage dry matter (DM) were carried out in the paddocks on a weekly basis). The size of the 24-hour breaks was then calculated to provide the required pasture allowances.

Pre-grazing pasture samples (cut to grazing height) were collected daily during each 3-day measurement period and bulked to give a separate sample for each treatment during each week. The samples were then split into two and analysed for dry matter content (oven dried $95^{\circ} \mathrm{C}$ for 48 hours), and chemical composition (after oven drying at $65^{\circ} \mathrm{C}$ for 48 hours) using near infrared spectrophotometry (NIRS systems 6500 with equations for different forages and silages determined using wet chemistry).

\section{Silage crops and measurements}

The ryegrass silage was harvested in early November 2000 and baled after 24 hours wilting. The Lotus and sulla silages were harvested in late November 2000 and baled after 48 hours wilting. Maize silage was harvested in late March 2000 and ensiled in a stack.

Before feeding each day a sample of each silage was quick-dried in a microwave to provide an approximate measure of DM content. These values were used to calculate how much fresh weight of each silage was required to supply $5 \mathrm{~kg} \mathrm{DM} / \mathrm{cow} / \mathrm{d}$.

Silage samples were also collected daily during each 3 -day measurement period and bulked to give a separate sample for each treatment during each week. The pasture and maize silage samples were then split into two and analysed for dry matter content (oven dried $95^{\circ} \mathrm{C}$ for 48 hours), and chemical composition (after oven drying at $65^{\circ} \mathrm{C}$ for 48 hours) using near infrared spectrophotometry (NIRS systems 6500 with equations for different forages and silages determined using wet chemistry). The Lotus and sulla silage samples were split into three and analysed as described above, while the third subsample was freeze dried and the CT concentration measured using the butanol-HCL colorimetric procedure (Terrill et al. 1992).

During the 3-day measurement periods each week the amount of silage left in the feed bins after 24 hours was weighed and sampled for determination of DM content. The daily silage intake ( $\mathrm{kg} \mathrm{DM} / \mathrm{cow} / \mathrm{d}$ ) on the respective treatments could then be calculated.

\section{Measurements}

Daily milk yield (p.m. plus a.m. milking) was measured over two days during the pre-trial uniformity period, and during each 3-day measurement period. Daily milk samples were also collected from each cow and analysed for the concentration of milkfat, milk protein and lactose using an infrared milk analyser (Milkoscan 133B, Foss Electric, HillerØd, Denmark).

Cow liveweight was also measured measured over two days during the pre-trial uniformity period and daily during each 3-day measurement period, before a.m. milking.

\section{Statistics}

There were two replicate groups of 5 cows on each of the six treatments giving 12 groups. Data were analysed using analysis of variance (Genstat 4.2) with group to group variation used as the error term. The uniformity data collected before the trial started was also used as a covariate for analysis of the milk parameters. 


\section{Results and Discussion \\ Pasture quality}

The increase in the proportion of reproductive stem associated with flowering and the build-up of dead material in the base of the sward during summer usually means that ryegrass dominant pastures are of lower quality during summer-autumn than spring pasture. The high fibre content, low digestibility and low ME concentration of the pasture consumed by cows during this trial are all indicators of relatively poor nutritional value (Table 1). Because of their higher allowance, cows on the full pasture treatment left a higher post-grazing herbage mass than those on the other treatments (2220 $\mathrm{kg} \mathrm{DM} / \mathrm{ha}$ vs. $1600 \mathrm{~kg} \mathrm{DM} / \mathrm{ha}$ ). Consequently the quality of pasture consumed by cows on the full pasture treatment was slightly better than that consumed by cows on the other treatments which were offered a restricted allowance (Table 1). In particular, the digestibility was higher, and the fibre content lower on the full pasture treatment than on other treatments.

\section{Silage quality and silage intake}

The pasture, maize and Lotus silages were all of good nutritional quality (Table 1) although they differed in crude protein and soluble carbohydrate levels as expected. For example, the maize silage had high soluble carbohydrate content but low crude protein concentration whereas the Lotus silage had a low soluble carbohydrate content but high crude protein concentration. Daily intakes of the pasture, maize and Lotus silages were all approximately $5 \mathrm{~kg} \mathrm{DM} / \mathrm{cow} / \mathrm{d}$ (Table 2 ). The sulla silage, however, had lower metabolisable energy (ME) content and digestibility, and higher fibre content, and was poorer nutritional quality than the other silages (Table 1) because the sulla was past optimum maturity when ensiled. The cows usually left the very fibrous sulla plant stems in the feed bins resulting in a lower daily intake of sulla silage compared with the other silages (Table 2).

As expected, only the Lotus silage and sulla silage contained CT (Table 1). The Lotus silage contained approximately twice the CT content of the sulla silage. In

Table 1 Average dry matter (DM) content and nutritional composition of the feeds offered to cows on the six treatments. ADF is acid detergent fibre. NDF is neutral detergent fibre. OMD is organic matter digestibility. ME is estimated metabolisable energy. CT is the total condensed tannin concentration. Units are all $\mathrm{g} / 100 \mathrm{~g}$ DM unless stated otherwise.

\begin{tabular}{lcccccc}
\hline & $\begin{array}{c}\text { Restricted } \\
\text { pasture }\end{array}$ & $\begin{array}{c}\text { Full } \\
\text { pasture }\end{array}$ & $\begin{array}{c}\text { Pasture } \\
\text { silage }\end{array}$ & $\begin{array}{c}\text { Maize } \\
\text { silage }\end{array}$ & $\begin{array}{c}\text { Lotus } \\
\text { silage }\end{array}$ & $\begin{array}{c}\text { Sulla } \\
\text { silage }\end{array}$ \\
\hline DM & 23.4 & 23.6 & 32.6 & 33.7 & 33.1 & 35.4 \\
Crude protein & 17.4 & 18.0 & 15.6 & 6.9 & 23.4 & 14.5 \\
Soluble carbohydrate & 9.7 & 10.2 & 5.9 & 31.6 & 2.6 & 3.6 \\
ADF & 26.4 & 24.2 & 31.1 & 27.0 & 27.5 & 40.6 \\
NDF & 47.5 & 45.3 & 46.8 & 44.5 & 35.5 & 50.8 \\
OMD & 67.3 & 71.0 & 71.0 & - & 69.2 & 63.4 \\
ME (MJ/kg DM) & 10.0 & 10.1 & 11.1 & 10.4 & 10.9 & 10.2 \\
PH & - & - & 4.38 & 3.83 & 4.43 & 4.40 \\
Lactic acid & - & - & 5.6 & 3.2 & 10.8 & 6.9 \\
Ammonia-N (\% total N) & - & - & 6.7 & 0.8 & 7.7 & 3.4 \\
CT & 0 & 0 & 0 & 0 & 3.37 & 1.63 \\
\hline
\end{tabular}

Table 2 Daily pasture and silage allowances $(\mathrm{kg} \mathrm{DM} / \mathrm{cow} / \mathrm{d})$, milk yield $(\mathrm{kg} / \mathrm{cow} / \mathrm{d})$, milksolids yield ( $\mathrm{kg}$ MS/ cow/d), milkfat concentration (\%), milk protein concentration (\%), dry matter intakes (DMI; kg DM/ cow/d) and substitution rate of cows on the six treatments.

\begin{tabular}{lcccccccc}
\hline & $\begin{array}{c}\text { Restricted } \\
\text { pasture }\end{array}$ & $\begin{array}{c}\text { Full } \\
\text { pasture }\end{array}$ & $\begin{array}{c}\text { Pasture } \\
\text { silage }\end{array}$ & $\begin{array}{c}\text { Maize } \\
\text { silage }\end{array}$ & $\begin{array}{c}\text { Lotus } \\
\text { silage }\end{array}$ & $\begin{array}{c}\text { Sulla } \\
\text { silage }\end{array}$ & SED & P \\
\hline Pasture allowance & 25 & 50 & 25 & 25 & 25 & 25 & & \\
Silage allowance & 0 & 0 & 5 & 5 & 5 & 5 & & \\
Milk yield & 13.05 & 17.04 & 15.02 & 14.97 & 17.23 & 15.13 & 0.22 & $<0.001$ \\
Milksolids yield & 1.00 & 1.29 & 1.11 & 1.12 & 1.29 & 1.10 & 0.03 & $<0.001$ \\
Milkfat & 4.48 & 4.29 & 4.20 & 4.29 & 4.12 & 4.19 & 0.10 & n.s. \\
Milk protein & 3.23 & 3.29 & 3.24 & 3.21 & 3.37 & 3.23 & 0.03 & $<0.05$ \\
Total DMI & 12.5 & 18.5 & 17.0 & 16.6 & 17.2 & 15.7 & 0.3 & $<0.001$ \\
Pasture DMI & 12.5 & 18.5 & 12.0 & 11.8 & 12.2 & 12.1 & 0.3 & $<0.001$ \\
Silage DMI & - & - & 5.0 & 4.8 & 5.0 & 3.6 & 0.2 & $<0.001$ \\
Substitution rate & - & - & 0.10 & 0.14 & 0.06 & 0.10 & 0.04 & $<0.001$ \\
\hline
\end{tabular}


both silages most of the CT was already bound ( $86 \%$ of CT bound in the Lotus silage and $91 \%$ of CT bound in the sulla silage), mainly to protein. This compares with fresh Lotus or sulla where only approximately $30 \%$ of $\mathrm{CT}$ are already bound before entering the rumen (Alley et al. 2002). This may mean that when Lotus silage and sulla silage are fed as supplements the $\mathrm{CT}$ are not available to bind with and thus protect proteins from other forages in the diet eg. fresh pasture.

\section{Total dry matter intake, milk production and milk composition}

Silage supplementation, regardless of silage type, increased both total dry matter intake (DMI) and milk production when compared with the control restricted pasture treatment (Table 2). Cows on the Lotus silage supplement, and the full pasture treatment had significantly higher milk yields than the other silagesupplemented cows, all of which had similar milk yields (Table 2).

Cows given the Lotus silage produced more milk than those on the other silage treatments (Table 2) probably due to a combination of the high nutritive value of the silage, and the action of CT in the silage. Woodward $e t$ al. $(1999,2001)$ demonstrated that $42 \%$ of the increase in milk yield when cows in mid- to late-lactation were fed a sole diet of fresh Lotus corniculatus instead of perennial ryegrass was a result of the action of CT. Because, in the current trial the Lotus was fed as a supplement and made up only $29 \%$ of the cows' daily intake, the effect of CT on milk production would have been expected to be smaller than if Lotus was fed as a sole diet. The total DMI of the Lotus silage cows was no different to that of cows on either the pasture silage or maize silage treatments (Table 2) which suggests that DMI does not account for the higher milk yield on the Lotus silage treatment compared with these treatments.

The higher milk yield of the full pasture treatment compared with the control pasture treatment was mainly a result of the cows having a significantly higher pasture DMI (Table 2). The slightly higher quality of pasture consumed by the full pasture cows probably contributed only slightly to the higher milk production of these cows compared with the control pasture treatment.

Feeding silage did not affect the overall milkfat concentration in any of the treatments averaged across the 4 weeks of the trial (Table 2). However, the Lotus silage treatment had a slightly higher milk protein concentration $(\mathrm{P}<0.05)$ than any of the other treatments averaged across the 4 weeks of the trial (Table 2). Previous trials have shown an increase in milk protein concentration of cows fed a sole diet of fresh Lotus compared with those fed perennial ryegrass during summer-autumn, mainly due to the action of CT (Harris et al. 1998;
Woodward et al. 1999).

Substitution rate defines to what extent a supplement replaces pasture in the diet. A value of zero means that pasture intake remains the same while a value of one means that the supplement completely replaces the pasture ie. total intake does not increase. Low pasture substitution rate must be achieved if feeding silage is going to increase milksolids production. The pasture DMI of cows receiving silage supplements were similar to the pasture DMI of cows on the restricted pasture (control) treatment with low values for substitution rate (all below 0.20). Thus, once cows had adjusted to their silage supplement, feeding silage to the cows reduced their pasture DMI only slightly, particularly for cows on the Lotus silage treatment which had the lowest substitution rate (Table 2).

The use of silage supplementation to increase summerautumn milksolids production on commercial dairy farms is dependent on economic viability. Preliminary economic farm surplus (EFS) analysis of the present data, based upon the additional milksolids income, the costs associated with growing (including land charges) and making the silage on-farm, and feeding costs per cow, suggested the Lotus silage was the most economic silage supplement, whereas feeding maize silage resulted in a financial loss per cow. However, this outcome was dependent on the silages correcting a nutritional deficiency in late summer when pasture quality was poor, rather than for correcting a pasture shortage. Lotus silage alone may not be an optimal supplement if the quantity of pasture is inadequate because DM yields of Lotus are low compared with maize silage or pasture. Better milk production responses may be achieved from cows on poor quality summer pasture if Lotus silage was fed as a protein supplement in combination with maize silage that would provide a source of soluble carbohydrate. The economic viability of such a feeding regime will require future research in whole farm systems.

More recent research (Chaves et al. 2002) has also indicated that such supplementation regimes may not result in significant production responses if summer pasture quality is high, such as in a wet summer, or if silage quality is poor. This is consistent with previous findings using a range of different silage types (Mackle \& Bryant 1994). Further questions concern whether feeding alternative forages to dairy cows earlier in lactation, for example in the period between calving and mating, would result in either milk production, liveweight gain, or improved reproductive performance responses.

\section{Summary}

The current trial has demonstrated, at least over a shortterm period, the potential benefit of silage supplementation, particularly with Lotus silage, for increased milksolids yield in summer-autumn when low 
pasture quantity and quality may otherwise limit production. On a farm scale, suitable alternative forages must provide adequate DM yields and increase milksolids production per hectare at least above that produced by cows grazing normal ryegrass/white clover pasture, without compromising milk composition or whole farm profitability.

\section{ACKNOWLEDGEMENTS}

This research was fully funded by the New Zealand Dairy Board Global Programme. Thank you to the Dexcel Feed Production Group and No 5 Dairy staff, and Simon Woodward for assistance with running of the trial. Thank you also to Barbara Dow for statistical analysis of data.

\section{REFERENCES}

Alley, E.M.K.; Woodward, S.L.; Waghorn, G.C.; Laboyrie, P.G. 2002. The impact of ensiling legume forages on condensed tannins. Proceedings of the Agronomy Society of New Zealand: In press.

Bryant, A.M.; Morgan, P.M. 1992. The production performance of large herds supplying the NZ Dairy Group. Proceedings of the $23^{\text {rd }}$ Large Herds Conference: 29-31.

Chaves, A.V.; Woodward, S.L.; Waghorn, G.C.; Brookes, I.M.; Holmes, C.W.; Laboyrie, P.G. 2002. Post-peak supplementation of pasture fed dairy cows with sulla and maize silages. Proceedings of the New Zealand Grassland Association 64: 125-128.

Clark, D.A. 1995. Summer milk - pasture and crops.
Proceedings of the Ruakura Farmers' Conference 47: 10-16.

Harris, S.L.; Clark, D.A.; Laboyrie, P.G. 1998. Birdsfoot trefoil - an alternative legume for New Zealand dairy pastures. Proceedings of the New Zealand Grassland Association 60: 99-104.

Mackle, T.R.; Bryant, A.M. 1994. How good is pasture? Proceedings of the Ruakura Farmers' Conference 46: 10-16.

Terrill, R.H.; Rowan, A.M.; Douglas, G.B.; Barry, T.N. 1992. Determination of extractable and bound condensed tannin concentrations in forage plants, protein concentrate meals and cereal grains. Journal of the Science of Food and Agriculture 58: 321-329.

Waghorn, G.C. 2002. Can forages match concentrate diets for dairy production? Proceedings of the New Zealand Society of Animal Production 62: 261-266.

Waghorn, G.C.; Ulyatt, M.J.; John, A.; Fisher, M.T. 1987. The effect of condensed tannins on the site of digestion of amino acids and other nutrients in sheep fed on Lotus corniculatus L. British Journal of Nutrition 57: 115-126.

Woodward, S.L.; Auldist, M.J.; Laboyrie, P.G.; Jansen, E.B.L. 1999. Effect of Lotus corniculatus and condensed tannins on milk yield and milk composition of dairy cows. Proceedings of the New Zealand Society of Animal Production 59: 152-155.

Woodward, S.L.; Jansen, E.B.L.; Laboyrie, P.G. 2001. Condensed tannins in legumes increase milk production in dairy cows. Journal of Dairy Science 84 Suppl. 1: 222-223. 